\title{
INTERAKSI EDUKATIF BERWAWASAN GENDER DI SMA NEGERI 2 UNGGUL SEKAYU SUMATERA SELATAN
}

\author{
INDAH WIGATI
}

\begin{abstract}
The purpose of writing is to get a picture of how gender-oriented educational interaction that occurs in SMA Sekayu South Sumatra? From the above explanation it can be concluded that; the educational interaction that takes place in SMA Negeri 2 Unggul Sekayu Palembang runs well and there is no discrimination in interacting either during learning process or beyond learning. Educational intercommunication that took place in SMA Negeri 2 Unggul Sekayu was implemented in all school stakeholders both in teachers, students, principals, staff, parents, school committees, cafeterias, and security officers.
\end{abstract}

Kata Kunci: Interaksi Edukasi, Gender

\section{A. PENDAhuluan}

Setiap manusia yang hidup di dunia ini, tidak bisa hidup tanpa berinteraksi. Interaksi yang berlangsung dalam kehidupan ini dapat diubah menjadi interaksi yang bernilai edukatif. Interaksi dapat disebut interaksi edukatif apabila secara sadar mempunyai tujuan untuk mendidik dan untuk mengantarkan anak didik kearah kedewasaannya. Interaksi edukatif sangat penting untuk mencapai tujuan pengajaran yang akan disampaikan.

Dalam mencapai tujuan pengajaran peranan guru sangat penting agar interaksi edukatif dapat berjalan dengan baik. Guru merupakan pendidik, yang menjadi tokoh, panutan dan identifikasi bagi para peserta didik, dan lingkungannya. Oleh karena itu, guru harus memiliki standar kualitas tertentu, yang mencakup tanggung jawab, wibawa, mandiri dan disiplin. Menurut penganut fungsionalis semua pihak (sekolah) harus menyadari bahwa penekan siswa pada kehendak masyarakat, bukan pada 
keinginan individu, atas dasar ini maka tugas guru adalah: Pertama, mendorong kesetiaan dan tanggung jawab siswa ketika hidup dalam lingkungan kelompoknya. Kedua, memperkuat kesadaran siswa dalam membangun kesetiaanya terhadap cita-cita dan nilai-nilai kelompok, mendahulukan kepentingan umum daripada kepentingan pribadi atau keluarga. Ketiga, mengembangkan dan mematangkan skill siswa dengan keahlian yang diperlukan masyarakat, dan yang diperlukan siswa untuk bersaing secara ketat di tengah-tengah kehidupan masyarakat. ${ }^{1}$

Kebanyakan guru seharusnya menjadi pendidik anak didiknya tetapi kurang optimal dalam pengajarannya karena kurangnya komunikasi edukatif dan interaksi pembelajaran yang kurang antara guru dan siswanya. Sehingga murid merasa bosan dan pembelajaran untuk mendidik siswa jadi tidak optimal. Dalam hal ini yang menjadi pokok adalah maksud dan tujuan berlangsungnya interaksi tersebut, karena kegiatan interaksi itu memang direncanakan atau disengaja. Kesadaran dan kesenjangan melibatkan diri dalam proses pembelajaran pada diri siswa dan guru akan dapat memunculkan berbagai interaksi belajar. Karena itu, peranan guru menurut Shor (1987) yang dikutib Sudarman Danim adalah: 1) mengajukan pertanyaan-pertanyaan yang membantu siswa mengidentifikasi yang dihadapi siswa di masyarakat. 2) bekerja sama dengan siswa untuk menemukan ide-ide yang menjelaskan pengalaman hidup mereka. 3) serta analisis yang mendorong pengalaman masyarakat sebagai dasar untuk memahami ajaran baru dan tindakan sosial atau penyadaran. ${ }^{2}$

Belajar mengajar adalah sebuah interaksi yang bernilai normatif, artinya didalam prosesnya anak didik berpegang pada ukuran, norma dan nilai yang diyakininya. Setiap interaksi belajar mengajar pasti bertujuan. Tujuan ini menentukan cara dan bentuk interaksi. Dalam mengajar terjadi suatu proses menguji strategi dan rencana yang memungkinkan timbulnya 
perbuatan belajar pada siswa serta dalam mengevaluasi dari apa yang dilakukan oleh peserta didik.

Interaksi edukatif harus menggambarkan hubungan aktif dua arah dengan sejumlah pengetahuan sebagai mediumnya, sehingga interaksi itu merupakan hubungan yang bermakna dan kreatif. Semua unsur interaksi edukatif harus berproses dalam ikatan tujuan pendidikan. Karena itu, interaksi edukatif adalah suatu gambaran hubungan aktif dua arah antara guru dan anak didik yang berlangsung dalam ikatan tujuan pendidikan.

Terkait interkasi edukatif berwawasan gender yang berlangsung di Sekolah Menengah Atas (SMA) Negeri 2 Unggul Sekayu Palembang merupakan proses interaksi edukatif guru laki-laki dan perempuan terhadap peserta didik laki-laki dan perempuan yang berlangsung dalam proses pembelajaran. Sekolah tersebut merupakan satu-satunya sekolah percontohan dan mendeklarasikan dirinya sebagai sekolah yang berwawasan gender di SMA Negeri 2 Unggul Sekayu. Deklarasi tersebut di ungkapkan dalam rangka memperingati hari kesehatan nasional (HKN) ke-50 tahun, melalui komitmen tidak merokok dan car free day pada hari selasa (18/11 2014) bertempat di Aula sekolah. Atas dasar tersebut penelitian ini mengkaji interaksi edukatif berwawasan gender.

\section{B. INTERAKSI EDUKATIF DI SEKOLAH}

Interaksi berasal dari dua kata yaitu kata inter (antar), dan aksi (kegiatan). Jadi interaksi adalah kegiatan timbal balik. Dari segi terminologi "interaksi" mempunyai arti hal yang saling melakukan aksi; berhubungan; mempengaruhi; antar hubungan. ${ }^{3}$ Menurut Homans mendefinisikan interaksi sebagai suatu kejadian ketika suatu aktivitas yang dilakukan oleh seseorang terhadap individu lain diberi ganjaran atau hukuman dengan menggunakan suatu tindakan oleh individu lain yang menjadi pasangannya. Konsep yang dikemukakan oleh Homans ini 
mengandung pengertian bahwa suatu tindakan yang dilakukan oleh seseorang dalam interaksi merupakan suatu stimulus bagi tindakan individu lain yang menjadi pasangannya. ${ }^{4}$ Artinya interksi itu akan berjalan dengan baik apabila ada respon dan timbal balik dengan orang yang bersangkutan. Menurut Profesor Djaali interaksi dalam pendidikan ada empat yaitu: 5

1. Interaksi murid dengan murid, dalam proses pembelajaran interaksi yang baik antar siswa dengan siswa sangat mempengaruhi minat belajar seorang siswa.

2. Interaksi murid dengan guru, interaksi ini berjalan saat proses pembelajaran berlangsung.

3. Interaksi murid dengan sumber belajar. Dalam pendidikan, sumber belajar merupakan suatu tempat yang digunakan mahasiswa untuk mencari sumber-sumber ilmu pengetahuan

4. Interaksi murid dengan lingkungan. Lingkungan pembelajaran merupakan salah faktor yang penting dalam berinteraksi dengan peserta didik, apabila siswa nyaman dengan lingkungan yang ada maka akan mempengaruhi siswa dalam pembelajaran.

Ada beberapa faktor yang mempengaruhi kualitas pembelajaran guru menurut Dunkin yang dikutib oleh Wina Sanjaya: Pertama, Teacher formative experience, semua pengalaman hidup guru yang melatar belakangi hidup mereka. Yang termasuk ke dalam aspek ini antara lain adalah tempat asal kelahiran guru termasuk suku, latar belakang budaya dan adat istiadat, keadaan keluarga dari mana guru itu berasal. Kedua, teacher training experince, meliputi pengalaman-pengalaman yang berhubungan dengan aktivitas dan latar belakang pendidikan guru, misalnya, pengalaman latihan profesional, tingkatan pendidikan dan lain sebagainya. Ketiga, Teacher properties adalah segala sesuatu yang berhubungan dengan sifat yang dimiliki guru terhadap profesinya, sikap 
guru terhadap siswa, kemampuan atau intelegensi guru, motivasi dan kemampuan mereka baik kemampuan dalam pengelolahan pembelajaran termasuk di dalamnya kemampuan merencanakan evaluasi pembelajaran maupun kemampuan dalam penguasaan materi pelajaran. ${ }^{6}$ Dengan demikian bahwa interaksi dapat berlangsung dengan baik apabila seorang guru mempunyai latar belakang pengalaman menjadi seorang guru, mempunyai pengalaman pelatihan profesional serta kemampuan seorang guru dalam memahami karakteristik siswa serta kemampuannya dalam menyampaikan materi dan mengevaluasi.

Menurut Sardiman 7 interaksi yang dikatakan dengan interaksi pendidikan apabila secara sadar mempunya tujuan untuk mendidik, untuk mengantarkan anak didik ke arah kedewasaan". Jadi dalam hal ini yang penting bukan bentuk interaksinya, tetapi yang pokok adalah maksud atau tujuan berlangsungnya interaksi itu sendiri. Karena tujuan menjadi hal yang pokok, maka kegiatan interaksi itu memang direncana atau disengaja. Sebagaimana disebutkan dalam berbagai referensi belajar mengajar, bahwa proses pengajaran pada hakekatnya merupakan rangkaian kegiatan komunikasi antara subjek didik, guru dan peserta didik.

Menurut Wina Sanjaya ada faktor-faktor yang mendasari terjadinya interaksi edukatif adalah sebagai berikut: ${ }^{8}$ Pertama, Faktor tujuan. Tujuan merupakan komponen yang sangat penting dalam sistem pembelajaran. Tujuan diibarakan sebagai jantung pada sistem pembelajaran. Jika tujuan itu menjado jantung dalam pendidikan maka proses pendidikan tidak akan berlangsung tanpa adanya tujuan.

Kedua, Faktor bahan/materi/isi Penguasaan bahan oleh guru seyogyanya mengarah pada spesifik/ takhasus atas ilmu kecakapan yang diajarkanya. Mengingat isi, sifat, dan luasnya ilmu, maka guru harus mampu menguraikan ilmu atau kecakapan dan apa-apa yang akan di 
ajarkanya kedalam bidang ilmu atau kecakapan yang bersangkutan. Penyusunan unsure-unsur atau informasi-informasi yang baik itu bukan saja untuk mempermudah peserta didik untuk mempelajarinya, melainkan juga memberikan gambaran yang jelas sebagai petunjuk dalam menetapkan metode pengajaran. Isi bahan pengajaran itu luas sekali dan berbeda dalam tinggi rendah serta sukar mudahnya. Macamnya pun banyak. Karenanya, sebelum menentukan bahan study pengajaran yang akan di pelajari oleh peserta didik perlu di adakan pilihan terlebih dahulu. Pilihan itu biasanya berdasarkan pada pedoman-pedoman tertentu agar keseluruhan bahan yang telah di tentukan itu teratur dan mencerminkan suatu hal yang integral bagi hidup peserta didik selama di sekolah sekarang, dan sesudahnya. Yang menentukan pedoman tersebut ialah pihak Depdikbud.isi pedoman yang di maksud adalah di sekitar kesesuaian bahan pengajaran dengan tujuan institusional, tujuan kurukulum, tujuan pengajaran, serta tujuan pendidikan pada umumnya dan haluan Negara . selain itu, bahan pengajaran pula harus disesuaikan dengan tingkatan jenjang pendidikan, tahap perkembangan jiwa dan jasmani peserta didik serta kebutuhan-kebutuhan yang ada pada mereka.

Ketiga, Faktor guru dan peserta didik. Guru dan peserta didik adalah dua subjek dalam berinteraksi pengajaran. Guru sebagai pihak yang berinisiatif awal untuk penyelenggaraan pengajaran, sedankan peserta didik sebagai pihak yang secara langsung mengalami dan mendapatkan manfaat dari peritiwa belajar mengajar yang terjadi. Guru sebagai pengarah dan pembimbing berdasarkan tujuan yang telah di tentukan, sedang peserta didik ialah sebagai yang menuju pada arah tujuan melalui aktifitas dan berinteraksi langsung dengan lingkungan sebagai sumber belajar atas bimbingan guru. Jadi kedua pihak ( guru dan peserta didik) menunjukan sebagai dua subjek pengajaran yang samasama menempati status yang penting. 
Keempat, Faktor metode. Metode adalah suatu kata kerja yang sistematik dan umum. Ia berfungsi sebagai alat untuk mencapai satu tujuan. Makin baik suatu metode makin efektif pula dalam pencapaianya. Tetapi tidak ada satu metode pun yang di katakana paling baik/ dipergunakan bagi semua macam usaha pencapaian tujuan, baik tidaknya , tepat tidaknya satu metode di pengaruhi oleh berbagai faktor. Faktor utama yang menentukan metode adalah tujuan yang akan dicapai. Metode mengajar/pengajaran, selain ditentukan/dipengaruhi oleh tujuan juga oleh faktor kesesuaian dengan bahan, kemampuan guru untuk menggunakannya, keadaan peserta didik, dan situasi yang melingkupinya.

Kelima, Faktor Media/Alat peraga adalah segala sesuatu yang dapat digunakan dalam rangka mencapai tujuan pembelajaran. Alat tidak hanya sebagai pelengkap, tetapi juga sebagai pembantu mempermudah usaha mencapai tujuan. Media ini juga berfungsi sebagai memahami mempermudah materi yang disampaikan oleh guru. Sehingga tujuan dan hasil belajar sesuai dengan harapan seorang guru.

Keenam, Faktor evaluasi. Evaluasi adalah suatu kegiatan yang dilakukan untuk mendapatkan data tentang sejauh mana keberhasilan anak didik dalam belajar dan keberhasilan guru dalam mengajar. Evaluasi dapat dilakukan oleh guru dengan memakai seperangkat istrumen penggali data seperti tes perbuatan, tes tertulis dan tes lisan.

Dari paparan interaksi edukatif di atas dapat dipahami bahwa proses interaksi di sekolah dapat berlangsung dimulai dari peserta didik datang kesekolah, pelaksanaan proses pembelajaran dan sampai pulang sekolah. Bukan hanya berinteraksi dengan guru saja tetapi proses interkasi dengan seluruh civitas sekolah baik dengan pos keamanan, guru, kepala sekolah, cleaning servis, komite sekolah dan pelangggan sekolah. 


\section{HAKEKAT GENDER}

Gender berasal dari bahasa Inggris, yang punya makna "jenis kelamin". ${ }^{9}$ Sementara itu istilah jenis kelamin biasanya mengacu pada ciri organ biologis, seperti payudara, rahim, vagina, dan ovum untuk perempuan; dan memiliki penis dan sperma untuk laki-laki. Dengan demikian, arti gender yang semacam itu menjadi sama dengan sex (jenis kelamin), yang memfokuskan pada perbedaan aspek biologis dari seorang manusia, yaitu laki-laki dan perempuan. Gender merupakan perbedaan sifat, peran, tangungjawab, fungsi, hak dan perilaku antara laki-laki dan perempuan sebagaimana hasil konstruksi sosial budaya masyarakat. ${ }^{10}$ Berpijak pada pandangan di atas, dapat dikemukakan bahwa gender adalah suatu konsep yang digunakan untuk membedakan antara laki-laki dan perempuan dilihat dari segi sosial-kultural masyarakat setempat. Oleh karena itu, identitas gender merupakan hasil dari social construct (konstruksi sosial), sehingga berbeda tempat dan berbeda masyarakat bisa jadi identitas gender yang dikembangkan berbeda. Di samping itu, berbeda waktupun identitas gender bisa pula berbeda.

Berhubungan dengan interkasi edukatif guru terhadap peserta didik maka guru harus mempunyai sensitivitas gender dalam mengajar. Peran guru sangat penting dan strategis pada semua fungsi pendidikan. Dalam rangka mempersiapkan anak menuju kehidupan yang demokratis, yang di dalamnya antara lain ditandai oleh nilai-nilai kehidupan yang egalitarian, peran guru sangat penting sebagai agen sosialisasi gender. Makin rendah jenjang pendidikan, makin penting peran ini, karena pada masa tersebut konstruksi nilai anak masih mudah dibentuk (dipengaruhi). Pada usia 8 tahun anak sangat rigid dalam memikirkan semua topik dan cenderung berlebihan dalam menggeneralisasikan fakta-fakta baru yang ditemukannya. ${ }^{11}$ 
Sosialisasi gender berawal di rumah dan terus berlanjut pada lingkup pergaulan yang lebih luas dan tingkat-tingkat pendidikan selanjutnya. Jenis informasi dan pengalaman belajar yang dialami anak berperan penting dalam sosialisasi gender, dan hal ini sangat diwarnai oleh gurunya. Pengalaman belajar yang diwarnai oleh konstruksi gender tradisional akan mengukuhkan kerangka gender tradisional yang mungkin telah dimiliki anak, karena masih banyak pengalaman sosialisasi di rumah yang diwarnai oleh konstruksi gender tradisional. Di lain pihak, pengalaman belajar yang diwarnai oleh konstruksi gender yang berbeda dengan konstruksi gender awal dari anak akan memberikan alternatif pengalaman kepada anak yang dapat memengaruhi bahkan mengubah konstruksi gender anak yang tradisional. Di sinilah peran penting pendidikan, sekolah, dan guru dalam sosialisasi gender.

Di sekolah, guru paling banyak menciptakan pengalaman belajar. Karena itu perlakuan guru, interaksi yang diciptakan guru, pernyataan, respon atau hal-hal lain yang dilakukan guru merupakan sumber belajar bagi anak. Bagi banyak anak, guru adalah sebagai sumber informasi, model identifikasi, dan imitasi. ${ }^{12}$ Peran tersebut semakin penting karena buku teks yang dipergunakan di sekolah masih banyak yang bias gender. Buku-buku teks di sekolah melalui kalimat dan gambar-gambarnya masih sering bias gender dengan memberikan keutamaan kepada laki-laki (patriarkhi). Buku ajar begitu juga kurikulum, yang belum berdasarkan peran gender seimbang ini akan dapat menyebabkan perempuan tetap tidak mempunyai mentalitas yang produktif. ${ }^{13}$ Informasi yang bias gender dalam jangka panjang memberikan dampak yang berbeda terhadap perkembangan anak laki-laki dan perempuan. Buku-buku teks yang dibaca dapat memengaruhi sikap dan opini anak. Kalimat-kalimat yang dibaca anak bisa berubah menjadi ideologi bila kelak ia dewasa. ${ }^{14}$ Semua ini terjadi karena di setiap buku selain tujuan kurikuler juga terkandung 
tujuan kurikuler tersembunyi (hidden curriculum) yang berupa nilai-nilai yang diharapkan tertanam pada diri siswa. Karena itu guru disarankan dapat memilih buku yang tidak bias gender atau paling tidak dapat memberikan respons yang positif terhadap materi bias gender dalam buku-buku yang terpaksa dipergunakan. ${ }^{15}$

\section{INTERKASI EDUKATIF BERWAWASAN GENDER DI SMA NEGERI 2 UNGGUL SEKAYU}

Proses interkasi edukatif yang berlangsung di SMA Negeri 2 Unggul Sekayu meliputi proses berinteraksi yang berlangsung antara peserta didik dengan peserta didik, peserta didik dengan guru, peserta didik dengan sumber belajar dan peserta didik dengan lingkungan sekolah serta interkasi guru dengan wali murid atau orang tua. Kemampuan guru dalam berinteraksi dengan peserta didik, sumber belajar dan orang tua di SMA Negeri Unggul Sekayu sangat penting dalam mewujudkan sekolah yang berwawasan gender, sehingga adanya keseimbangan bagi siswa lakilaki dan perempuan untuk dapat saling menghargai.

Berdasarkan observasi dalam berinteraksi dengan warga sekolah baik interaksi siswa dengan siswa, interaksi siswa dengan guru, interaksi siswa dengan sumber belajar, interaksi siswa dengan lingkungan sekolah ada prinsip $5 \mathrm{~S}$ yang digunakan yaitu senyum, sapa, salam, sopan, santun yang diterapkan di SMA Negeri 2 Unggul Sekayu dalam berinteraksi di sekolah tersebut. Hasil pengamatan kepada siswa di SMA Negeri 2 Unggul saat interaksi antar siswa dengan siswa, antar siswa dengan siswa saat bertemu saling menyapa dan tersenyum walaupun mereka bukan dari kelas yang sama, saling menghargai antar senior dan yunior, dimana yunior bersalaman dan menundukakan kepala saat mereka bertemu. Tidak nampak kekerasan dan diskrimansi antar kelas senior dengan 
yunior. Sikap senyum, sapa, sopan dan santun yang diterapkan di sekolah ini memang diberikan kepada seluruh siswa saat sudah diterima di sekolah tersebut. Perilaku sopan dan santun ini benar-benar menjadi kebiasaan para peserta didik, sehingga saat luar sekolah para siswa juga berprilaku yang sama yaitu senyum, sapa, sopan dan santun. Lingkungan yang aman dan nyaman yang diciptakan oleh sekolah dalam berinteraksi sesama siswa menyebabkan siswa merasa betah. Sosialisasi $5 \mathrm{~S}$ diberikan kepada peserta didik saat mengikuti orientasi sekolah di SMA Negeri 2 Unggul Sekayu. Hasil wawancara pada siswa dan siswi dalam menjalin hubungan setara teman tanpa diskriminasi dalam gender yaitu harus berteman dengan siapa pun, tidak memandang apakah dia laki-laki maupun perempuan.

Berdasarkan hasil wawancara kepada wali murid interaksi yang terjalin antara guru dan orang tua dapat dilakukan melalui media komunikasi telepon atau dapat mendatangi secara langsung di sekolah untuk mengetahui perkembangan anaknya. Komunikasi ini juga bertujuan untuk mengetahui anak-anaknya masuk sekolah atau tidak agar terhindar dari siswa yang bolos sekolah, di samping itu dengan adanya komunikasi ini untuk mengetahui prestasi-prestasi yang diperoleh peserta didik di dalam kelas maupun pada kegiatan ekstrakulikuler sekolah. Hasil wawancara kepala sekolah intensitas kepala sekolah dengan warga sekolah dalam satu semester sering sekali dilakukan tidak dapat dihitung berapa kalinya. Hasil wawancara ketua komite sekolah tentang seberapa sering sekolah memberikan peluang orang tua berkomunikasi kepada anaknya yang diketahui oleh komite sekolah didapatkan sebagai berikut:

Jadi untuk pertemuan orang tua sekolah yang pertama orang tua tersebut bisa jadi komite sekolah nah pertemuan ini untuk kelas $X$ biasanya dilakukan di awal masuk sebagai siswa baru kemudian pada saat pembagian raport dan yang ke tiga pembagian raport akhir semester. 
Untuk kelas XI yang pertama raport MID kemudian semester dan juga dalam 1 semester dan juga ada yang perlu di musyawarakan dan untuk kelas XII barang kali frekuensinya agak lebih banyak pertama pada saat MID kemudian rapot semester pembahasan untuk sosialisasi ujian Nasional dan yang 3 penerimaan masukan SPMB untuk perguruan tinggi. ${ }^{16}$

Dengan demikian, tugas sekolah terhadap masyarakat telah terlaksana yaitu sekolah harus selalu berinteraksi dengan kehidupan masyarakat sehingga kebutuhan kedua pihak akan terpenuhi. ${ }^{17} \mathrm{Di}$ samping itu, peran orang tua yang harus secara aktif mengkomunikasikan berbagai informasi tentang kondisi dan permasalahan yang mempengaruhi belajar anak di dalam keluarga. Tujuan komunikasi orangtua dengan guru agar para orang tua dapat mengontrol kemampuan dan perkembangan perilaku siswa, perkembangan akademik, keterampilan siswa di sekolah, kemampuan dalam berkomunikasi dengan sesama teman di kelas, guru serta pegawai di sekolah maupun dengan satpam dan cleaning service sekolah. Keterlibatan orang tua dengan sekolah dapat dilakukan melalui: Pertama, berusaha mengenal guru dan tenaga kependidikan lain di sekolah. Kedua, mengikuti pertemuan orangtua atau menjadi anggota komite sekolah. Ketiga, mengunjungi kelas untuk melihat perilaku anak-anak, berinteraksi dengan guru dan siswa lain. Keempat, mengikuti kegiatan-kegiatan yang diadakan sekolah. Kelima, menanyakan mengenai apa yang dilakukan anak dan yang terjadi di sekolah. Keenam, Mengupayakan untuk dapat terlibat dalam kegiatan ekstrakurikuler. ${ }^{18}$

Dalam berinteraksi antara orangtua murid dengan guru untuk mengetahui perilaku dan perkembangan anaknya, para orang tua tidak dibatasi waktu. Berdasarkan hasil wawancara kepada wali siswa yaitu para orang tua diberikan waktu seluasnya kapan para orang tua membutuhkan informasi tentang anaknya. Tetapi pada umumnya para 
orang tua minimalnya satu bulan sekali untuk berkomunikasi dengan para guru dengan tujuan para orang tua dapat mengetahui perkembangan anaknya di sekolah tersebut. Interaksi orang tua dengan guru dilakukan juga saat pembagian rapot mid semester dan rapot kenaikan kelas untuk kelas 10 dan 11. Di sana para orang tua dapat meminta penjelasan mengenai anak-anaknya. Khusus kelas 12 pertemuan antara orang tua dan guru lebih sering di adakan yaitu raport mid semester serta pembahasan untuk sosialisasi Ujian Nasional (UN) dan rapat mengenai penerimaan Seleksi Bersama Masuk Pergurun Tinggi Negeri (SBMPTN). Banyak interaksi orang murid kelas 12 disebabkan karena berharap anaknya dapat melaksanaka Ujian Nasional dengan baik sehingga dapat masuk ke perguruan tinggi ternama di Indonesia. Kegiatan orangtua dengan guru di atas merupakan bagian dari keterlibatan orang tua terhadap sekolah dalam berinteraksi dengan warga sekolah di SMA Negeri 2 Unggul Sekayu.

Intekasi guru dengan orangtua dapat juga dilakukan oleh para orang tua dengan mengikuti kegiatan dan terlibat aktif dalam kegiatan komite sekolah. Hal ini dapat dilihat dari hasil rapat komite sekolah dimana kepengurusan komite sekolah terdiri dari para orang tua wali murid yang terlibat menjadi kepengurusan dan anggota komite sekolah. Keterlibatan orang tua murid dalam kepengurusan ini agar para wali murid mengetahui secara langsung interksi siswa dengan guru di kelas dan di lingkungan sekolah. Hal ini sesuai dengan salah satu tugas sekolah terhadap masyarakat adalah sekolah harus selalu berinteraksi dengan kehidupan masyarakat sehingga kebutuhan kedua pihak akan terpenuhi.

Orang tua wali murid mengikuti kegiatan-kegiatan yang diadakan sekolah, misalnya perayaan hari Kartini yang dilaksanakan pada hari kamis 21 April 2016 dan kegiatan-kegiatan lain. Dalam kegiatan tersebut para wali murid mengikuti hari perayaan-perayaan tersebut. Keterlibatan 
orang tua dalam kegiatan-kegiatan sekolah agar para wali murid merasa memiliki dan ikut mengembangkan terhadap kegiatan yang dilakukan oleh pihak sekolah.

Pemberian materi tentang gender yang diberikan sekolah SMA Negeri 2 Unggul Sekayu diharapkan akan berpengaruh pada pola pikir pada siswa/siswi laki-laki dan perempuan, para guru dan para pegawai. Hal ini dapat dibuktikan saat diwawancarai pada siswa laki-laki maupun perempuan, para guru dan pegawai hasilnya mereka dapat menjelaskan tentang kesetaraan gender. Berdasarkan hasil penelitian Achmad Muthali'in menyatakan pengalaman pendidikan memberi pengaruh yang signifikan terhadap bentuk nilai-nilai dan pola pikir yang dikembangkan oleh para pendidik, dimana keseluruhan pengalaman tersebut berpengaruh terhadap mindset, pola sikap dan perilaku rasional antara laki-laki dan perempuan. ${ }^{19}$

Interaksi merupakan bagian dari interaksi sosial. Interkasi sosial merupakan hubungan-hubungan sosial yang dinamis yang menyangkut hubungan antara orang-orang-perorangan, antar kelompok-kelompok manusia, maupun antara orang perorang dengan kelompok manusia. ${ }^{20}$ Proses interaksi di sekolah menjadi sangat penting dalam mencapai visi dan misi sekolah serta tercapainya pembelajaran yang diinginkan. Interaksi edukatif merupakan syarat mutlak dalam sebuah proses pembelajaran. Tanpa adanya interaksi edukatif, maka proses pembelajaran akan sulit menjalankan fungsi dan perannya. Tanpa interaksi edukatif, proses pembelajaran pun kesulitan untuk mencapai tujuan yang telah ditetapkan sebelumnya. Namun demikian, tidak semua interaksi dapat disebut dengan interaksi edukatif, meskipun interaksi tersebut terjadi antara pendidik dan peserta didik. Dikatakan interaksi edukatif apabila hubungan timbal balik antara guru dan siswa dapat saling menguntungkan dengan kata lain materi yang disampaikan oleh guru 
dapat di terima oleh siswa dan dapat mempengaruhi langsung kemampuan dan perilaku siswa sehingga ada perubahan yang nyata pada diri siswa.

Interaksi merupakan bagian dari interaksi sosial. Interkasi sosial merupakan hubungan-hubungan sosial yang dinamis yang menyangkut hubungan antara orang-orang-perorangan, antar kelompok-kelompok manusia, maupun antara orang perorang dengan kelompok manusia. ${ }^{21}$ Proses interaksi di sekolah menjadi sangat penting dalam mencapai visi dan misi sekolah serta tercapainya pembelajaran yang diinginkan. Interaksi edukatif merupakan syarat mutlak dalam sebuah proses pembelajaran. Tanpa adanya interaksi edukatif, maka proses pembelajaran akan sulit menjalankan fungsi dan perannya. Tanpa interaksi edukatif, proses pembelajaran pun kesulitan untuk mencapai tujuan yang telah ditetapkan sebelumnya. Namun demikian, tidak semua interaksi dapat disebut dengan interaksi edukatif, meskipun interaksi tersebut terjadi antara pendidik dan peserta didik. Dikatakan interaksi edukatif apabila hubungan timbal balik antara guru dan siswa dapat saling menguntungkan dengan kata lain materi yang disampaikan oleh guru dapat di terima oleh siswa dan dapat mempengaruhi langsung kemampuan dan perilaku siswa sehingga ada perubahan yang nyata pada diri siswa.

\section{E. KESIMPULAN}

Dari paparan di atas dapat disimpulkan bahwa interaksi edukatif yang berlangsung di SMA Negeri 2 Unggul Sekayu Palembang berjalan dengan baik dan tidak ada diskriminasi dalam berinteraksi baik saat proses belajar berlangsung maupun diluar pembelajaran. Interkasi edukatif yang berlangsung di SMA Negeri 2 Unggul Sekayu dilaksanakan pada seluruh stakeholder sekolah baik pada guru, siswa, kepala sekolah, 
pengawai, orang tua siswa, komite sekolah, petugas kantin, dan petugas keamanan.

Penulis : Dr. Indah Wigati, M.Pd.I adalah Dosen Fakultas Ilmu Tarbiyah dan Keguruan Universitas Islam Negeri Raden Fatah, Jl. Prof. K.H Prof Zainal Abidin Fikri KM 3.5 Palembang, Email: indahwigati_tarbiyah@yahoo.co.id.

\section{DAFTAR PUSTAKA}

Zainuddin Maliki, Sosiologi Pendidikan, Gadjah Mada Universitas Press, Yogyakarta, 2010

Sudarwan Danim, Pengantar Kependidikan (Landasan Teori, dan 234 MetaforaPendidikan, Albeta), Bandung, 2010

http:/ /id.shvoong.com/social-sciences/education/2181039-pengertianinteraksi-edukatif/ di undu 12 April 2017

Homans dalam Alim, Pendididkan Agama Islam, Remaja Rosdakarya, Bandung, 2006

http:/ / hadiyan.wordpress.com/2012/08/30/empat-interaksi-pendidikanmenurut-profesor-djaali/ di undu tanggal 23 April 2017

Wina Sanjaya, Kurikulum dan Pembelajaran, Prenada Media Group, 2011

Sardiman AM. Interaksi dan Motivasi Belajar Mengajar. Rajawali Press. Jakarta, 2005

Echols, John M. dan Hassan Shadily. Kamus Inggris - Indonesia. Jakarta: PT Gramedia, 1984

Umar, N, Argumen Kesetaraan Gender: Perspektif Al-Quran, Jakarta: Paramadina, 2001 
Bryan, Janice Westlund dan Zella Luria, "Sex-Role Learning: A Test of Selective Attention Hypothesis", dalam Child Development, Volume 49, Maret 1978 (1):13-23. Chicago: University of Chicago Press, 1978

Ace Suryadi dan Cecep Idris, Kesetaraan Jender dalam Bidang Pendidikan Bandung: Genesindo, 2004

Murniati, Perempuan Indonesia dan Pola Ketergantungan, dalam Budi Susanto, et.al.(Ed.). Citra Wanita dan Kekuasaannya, Seri Siasat Kebudayaan Yogyakarta: Kanisius, 1992

Achmad Muthali'in, Bias Jender dalam Pendidikan (Surakarta: Muhammadiyah University Press, 2001

Kementerian Pendidikan Nasional, Acuan Pelaksanaan Sekolah Menengah Atas Berwawasan Gender, Jakarta: Kementerian Pendidikan Nasional, 2010

Soejono, Sosiologi Pendidikan, Jakarta: Rajawali Press, 2009

\footnotetext{
${ }^{1}$ Zainuddin Maliki, 2010, Sosiologi Pendidikan, Gadjah Mada Universitas Press, Yogyakarta, hlm. 133.

${ }^{2}$ Sudarwan Danim, 2010, Pengantar Kependidikan (Landasan Teori, dan 234 MetaforaPendidikan, Albeta), Bandung, hlm. 212-213

3 http://id.shvoong.com/social-sciences/education/2181039-pengertian-interaksi-edukatif/

di undu 12 April 2017

${ }^{4}$ Homans dalam Alim, 2006, Pendididkan Agama Islam, Remaja Rosdakarya, Bandung,.hlm. 87

${ }^{5}$ http://hadiyan.wordpress.com/2012/08/30/empat-interaksi-pendidikanmenurut-profesor-djaali/ di undu tanggal 23 April 2017

${ }^{6}$ Wina Sanjaya, 2011, Kurikulum dan Pembelajaran, Prenada Media Group, hlm. 198-199

7 Sardiman AM. (2005). Interaksi dan Motivasi Belajar Mengajar. Rajawali Press. Jakarta. Hlm. 8

${ }^{8}$ Wina, Kurikulum, hlm. 204-206

${ }^{9}$ Echols, John M. dan Hassan Shadily. Kamus Inggris - Indonesia. (Jakarta: PT Gramedia, 1984). h.265

${ }^{10}$ Umar, N, Argumen Kesetaraan Gender: Perspektif Al-Quran (Jakarta: Paramadina, 2001), h. 35

${ }^{11}$ Bryan, Janice Westlund dan Zella Luria, "Sex-Role Learning: A Test of Selective Attention Hypothesis", dalam Child Development, Volume 49, Maret 1978 (1):13-23. (Chicago: University of Chicago Press, 1978), hlm. 14. Anak-anak juga memegang kepercayaan mengenai peran-peran gender dengan sangat rigid. Dalam proses itu persetujuan guru pun merupakan cara yang paling efektif untuk mensosialisasikan peran gender pada anak. Dalam rangka sosialisasi nilai gender, guru merupakan sumber belajar dan model bagi anak dalam berimitasi dan identifikasi diri. Sikap dan perilaku gender guru sangat penting dalam memengaruhi dan mendekonstruksi gender
} 
anak. Lihat Jeanne Ellis Ormrod, Psikologi pendidikan (Membantu Siswa Tumbuh dan Berkembang), (Jakarta: Erlangga, 2008), hlm. 105

${ }^{12}$ Ibid, hlm. 64

${ }^{13}$ Ace Suryadi dan Cecep Idris, Kesetaraan Jender dalam Bidang Pendidikan (Bandung: Genesindo, 2004), hlm. 163.

${ }^{14}$ Murniati, Perempuan Indonesia dan Pola Ketergantungan, dalam Budi Susanto, et.al.(Ed.). Citra Wanita dan Kekuasaannya, Seri Siasat Kebudayaan (Yogyakarta: Kanisius, 1992), hlm. 28.

${ }^{15}$ Achmad Muthali'in, Bias Jender dalam Pendidikan (Surakarta: Muhammadiyah University Press, 2001), hlm. 95

${ }^{16}$ Wawancara kepada Ketua Komite sekolah yang diambil pada hari Rabu, 23 Maret 2015

${ }^{17}$ Idid, Sosiologi, hlm. 93

${ }^{18}$ Kementrerian, Panduan Sekolah, hlm.35

${ }^{19}$ Achmad Muthali'in, Bias Gender dalam Pendidikan. (Surakarta: Universitas Muhammadiyah Press, 2001), hlm.23

${ }^{20}$ Soejono, Sosiologi Pendidikan, (Jakarta: Rajawali Press2009), hlm.24

${ }^{21}$ Ibid 